\title{
Mind over Matter
}

\section{Peita Sykes}

As I WALK home from school, I turn my head to the left as I pass John's place. I have to walk on the footpath across the road from that house now. I'm not allowed near there anymore. I did something 'wrong.' I 'hurt' his Mum. I shouldn't even be in this street, but it's the most convenient way to get home. It cuts 28 mins and 20 seconds off my journey, so the judge made an exception, as long as I don't go in or talk to them.

As I open my front door, Karen reminds me I've gotta do community service tomorrow. God, she's annoying. Seriously, you'd think they'd give me someone who can actually speak English. 'I know! Just shut the fuck up!' That should teach her. No one can control me.

My laptop's been touched. It shouldn't be on my desk. I left it on my bed, sticking out $1 \mathrm{~cm}$ from under my pillow. 'Oi, leave my shit alone! You're a babysitter, not a fucking maid!' I hate people touching my stuff. It's mine. No one but me has the right to use my stuff! I wouldn't call me over-protective of my possessions, but they are mine and no one else's. Simple as that.

I start drawing to distract myself from my 'angry place'. I draw her. I pay close attention to portraying her smooth face, her flawless skin despite her 40 years. It would be better than mine at the moment; I've got a scab on my right cheek from when John punched me. It wasn't a bad shot, considering he got me by surprise. I could've done better damage. John's weak. He's over-protective of his possessions. He's afraid of the unusual. $\mathrm{Me}$, however, I embrace it. Mind over matter. Anything is possible. And for me, it was. I may be locked up, but what I did for us was definitely worth it. We got what we wanted. 
I'd been watching Tracey for years. She'd come to pick John up from school everyday and would always speak to his mates. I was one of those. One of his 'mates'. But clearly John, and the rest of society had a problem with my intentions, and now refuse to acknowledge my existence. But I couldn't help it. There was obviously something more than just a family -friend relationship between us. I was always welcomed over to their house. More than any other of John's 'mates'. She unmistakably liked me, and wanted me too.

Next come the neck and shoulders. I am sure to capture the soft touch of her left shoulder my right hand had once felt. It drifted under her bra strap and pulled it down her arm, after I had unclipped it from the back. My left hand was busy holding her fragile body down, so she wouldn't keep resisting our fate. But she did. I took it as a compliment and proceeded. I must say, there's no better turn on than a woman pressed up against a wall, squirming and struggling. I kept whispering the words, 'mind over matter' but she still thought about morals and laws. She didn't want to make love to a minor. So brainwashed by the government and the media. But it was that innocence and naiveté that I found sexy. I remember the look in her eyes as I caught a tear off her chin. She was trying to cover satisfaction with fear, but I saw through it. I let it go though; if that's what she wanted to do to make our first time seem more extreme then she had my permission. She just needed a man who appreciated her and granted her wishes. Someone like me and not the husband she had who left her to fend for herself and look after a teenage boy.

It's dark outside, but I'm not gonna turn the light on, because it's just the same shade as it was in Tracey's bedroom. That was forty three days ago. I haven't seen her since the trial, thirty eight days ago. I miss her. I know she misses me too. I've drawn 121 pictures of her since then, but only a total of 326 over the three years I've known her. I'm drawing now more than ever to make up for the nights I used to peep through the crack in her door when John and I would watch Big Brother on TV. She would always leave a $23 / 8$ inch gap so I could see. She led me on, then stabbed me in the back. But she felt she had no choice-no one would accept such a special relationship. I know I didn't lose my virginity to just anyone. I gave it to the love of my life.

Tracey must be missing me like crazy. I don't care what the consequences are, I'm gonna pay her a visit. It's the risk I have to take to make it work 
for us. I need to remind her I haven't forgotten her. Mind over matter. Anything is possible. And for me, it is. I may be locked up, but what I will do for us will definitely be worth it. We will get what we've always wanted.

As I enter Tracey's driveway, I see John having a ciggy on the verandah, 4.2 metres from me. I shove my $326^{\text {th }}$ sketch in the back slot of my jeans, right beside my pocketknife and keep walking. 